\title{
Towards Emancipatory Technology Studies
}

\author{
Philipp Frey $\mathbb{D} \cdot$ Simon Schaupp (D) \\ Klara-Aylin Wenten
}

Accepted: 28 February 2021 / Published online: 29 April 2021

(C) The Author(s) 2021

Contemporary society is obsessed with technology. Technology is supposed to secure economic growth in times of crises, civil unrest, (trade) wars and unsustainable public and private debt. In prevailing debates, it is supposed to help ecological systems recover whose delicate balance has been shaken and often upset by a political economy that is fundamentally indifferent to life. Against the backdrop of the advent of techno-utopianism in both libertarian and conservative forms and technologically mediated attacks on privacy and labour standards, critical scientists have often resorted to deconstructing existing discourses and criticising technological progress altogether. This urge is more than understandable, but it can reinforce the risk of reifying technology as the driving force behind problematic societal developments, rather than regarding it as the product of a politically contested field of socio-material practices.

\section{P. Frey $(\bowtie)$}

Institute for Technology Assessment and Systems Analysis

(ITAS), Karlsruhe Institute of Technology, Karlsruhe,

Germany

e-mail: philipp.frey@kit.edu

S. Schaupp

Department for Social Sciences, University of Basel, Basel, Switzerland

\section{K.-A. Wenten}

Munich Center for Technology in Society (MCTS),

Technical University of Munich, Munich, Germany
However, beyond this techno-utopianism and its critique, there is a growing body of literature aiming at exploring potentials for social emancipation in a highly technologised world. Besides feminist examinations of the relations between technology and gender (in)equality [1-3], ecology-centred reflections on sustainable futures [4] or investigations of the role automation could play for a post-capitalist society [5], activist research on possibilities of resistance and empowerment [6-8] seeks to discuss and play out alternatives to technological domination. In spite of their different (empirical and theoretical) perspectives, all these studies appear to share a similar understanding of emancipation that aims at abolishing domination and exploitation in current societies. Moreover, they inspire debate on the implications and effects that such a research focus might have for their socio-political practices as academics. In the following, we will build on these debates, combining traditions of critical theory, science and technology studies (STS) and critical sociology of work to advance an understanding of what may be called emancipatory technology studies (ETS).

By emphasising the role of technology in struggles for emancipation, this special section thus seeks to bring together theoretical and methodological accounts of ETS. In doing so, it refrains from hastily adopting deterministic perspectives on socio-technological progress and instead stresses the performative, relational, socio-economic and political character of both the social and the material. ETS thereby emphasizes the 
emancipatory quality that often "hides" behind terms such as participation, democratisation or even critique in the social sciences. With this special section, we want to continue debate on what it means to work on the role of emancipation in socio-technological development.

Why should researchers from disciplines such as STS, technology assessment or the sociology and philosophy of technology be interested in emancipatory perspectives on technology? The public sphere has been buzzing with technology-related discussions in recent years: in Germany, the vision of a socalled "Industry 4.0" was the focal point of technopolitical debates [9-11], but there have also been lively discussions revolving around the implications of autonomous driving [12,13], the use of digital systems in healthcare $[14,15]$, the impact of digital media on democracy [16-18], the transformation of energy systems $[19,20]$ or even a Green New Deal $[21,22]$. Therefore, scholars increasingly turn their attention to the rise of (new) technology in different fields of implementation, while still remaining highly ambivalent in their claims about socio-political and economic conditions: while one part of research has shifted to more or less restricted and biased commissioned research, not least because of its economic dependence on third-party funding, the other, more critical part has dedicated itself predominantly to self-sufficient analytical deconstruction. What remains mostly marginal within these debates is the development of positions more sceptical of pseudocritical complicity. A necessary critique of current social conditions and the technological apparatus they generate, combined with the question of the emancipatory potentials of technology, has so far remained underdeveloped. Yet, this perspective would be vital for critical academic debates dedicated to an empathically reasonable use of technology. ${ }^{1}$

To take one example: There are certainly reasons for political, trade union and scientific actors to take part in the debate on "Industry 4.0", also with regard to its concrete implementation [25]. However,

\footnotetext{
${ }^{1}$ In our emphatic use, we follow Marcuse's basal characterisation of critical reason as "a mode of thought and action which is geared to reduce ignorance, destruction, brutality, and oppression." [23] For a more elaborate attempt to develop a "reasonable" approach to reflecting on technological development, see [24].
}

the dominance of the "Industry 4.0" vision with its focus on global competitiveness threatens to massively narrow the debate on technology. In this way, on the one hand, social needs that are ultimately incompatible with this purpose-such as the need for people to be freed from the demands of an ultimately irrational mode of production-have no place in it. On the other hand, a criticism that limits itself to denouncing talk of "Industry 4.0" as ideological [26] does not transcend the narrowness of the debate in a sense that would enable speculations about possible alternative forms of technopolitics. Yet, it is precisely these perspectives around emancipatory alternatives bringing about positive societal change that we seek to express, discuss and critically engage with in this special section.

It seems difficult to generalise what is meant by "emancipation", as the notion is highly contextsensitive. So, how might research go about identifying the emancipatory potentials of technology? Let us start with a few general comments that will help guide us through this special section and that will be complemented and extended throughout the contributions to this section.

The term "emancipation" derives from the Latin term emancipatio, namely the act of freeing a slave or releasing a son from paternal supervision. From this origin, the term has developed further and today encompasses the liberation from a multitude of oppressive conditions-for example, women's struggle for liberation from patriarchal domination. The common denominator of emancipatory politics is that they are dedicated to dismantling societal power relations, or in the words of Marx ([27], p. 385): "overthrowing all relations in which the human being is a debased, enslaved, abandoned, despicable essence". This "overthrowing" cannot simply be proclaimed but necessarily involves the struggles of those actors who are themselves subject to a given form of domination [28].

It seems to us that an important contribution of emancipatory research to technology debates is to open up technology design and use to democratic negotiation in the first place. If research and innovation are largely left to private enterprises, technological developments will be determined by their specific economic rationale, inhibiting democratic deliberation in the form of an emancipatory implementation and design of these technologies. At the 
same time, the presentation of technologically mediated economic rationalisation as a kind of force of nature in public discourse tends to make arguments about its pros and cons rather obsolete-it is here, in the criticism of technological determinism, where deconstruction indeed has a key role to play in opening up discursive spaces. If necessary debates about the meaning and (non-)sense of innovation processes are blocked and the management of apparently inherent necessities takes their place, we are faced with a mode of societal management that, at best, can stimulate certain palliative measures. In our view, however, it is important to intervene in such debates in order to emphasise that the way in which technology changes is intimately connected to its socio-economic framework, whose transformation is the task of emancipatory practices. If people are unable to determine the conditions, meaning and purpose of this change, talk and action about emancipatory potentials of technology remain powerless. This tension is central to any emancipatory approach to technology and corresponds to a key tenet of emancipatory thought in general: namely, the conviction that people could be freed to consciously shape their own history.

To give an example here: The debate about impending technological unemployment is heated both in science and among the general public. New studies are regularly published, predicting a digitalisation-related decline in demand for human labour [29-31] —other studies counter that digitalisation can stimulate further economic growth, which might enable the reintegration of redundant workers into the labour market [32, 33]. Against this background, studies have problematised the socio-economic conditions driving automation as they shape the design and implementation strategies of technology, often in favour of the more dominant interest group [34-36]. Taking a step back and radically reflecting on the socio-economic conditions of technological development remains critical here: after all, the material wealth of a society does not decrease when, for example, robots replace humans in the work process. On the contrary, since automation technologies are used to increase productivity, the conclusion seems obvious that societal wealth will increase rapidly. What madness must have taken hold of a society when the fact that human needs might be satisfied by less human labour is considered a societal challenge, a scourge, rather than a blessing? And what changes to the socio-economic setting would be required to make sure that this madness can be materially overcome?

For us, questions like these already imply the search for socio-technical alternatives, e.g. for social conditions in which the advancement of the productive forces neither leads to impoverishment nor to ecological ruin. In our view, a specific contribution of ETS to this search for alternatives should not least consist in providing knowledge, based on the scientific examination of technological developments, on the unfulfilled emancipatory potentials that are ripe for the taking. Instead of maintaining existing social conditions as closely as possible in the future, ETS seeks to raise awareness of what might be possible if innovation embodied alternative, normative considerations and took place under qualitatively different social conditions [37-39].

We do not understand the dealing with said potentials simply as an expression of a flimsy optimism that naively assumes technology is a kind of autonomous and neutral force that, by itself, will accomplish the liberation of humankind. In view of the current weakness of emancipatory forces, this projection seems to be less useful at the theoretical level. From our point of view, it is not enough to simply reconstruct a teleological faith loaded with all sorts of hopes in the form of an affirmative technological determinism. Instead, we would like to suggest an attitude that Ernst Bloch once called "militant optimism" ([40], p. 201): a way of thinking that remains sworn to the as yet unfulfilled promises of happiness and freedom that are inherent in social relations, without suggesting that just because things could get better, they will. No technology, no matter how advanced, will simply liberate humanity - but hopefully, the debate on future socio-technical arrangements offers a starting point for negotiating how we want to live in the future and what technologies could make a positive contribution.

Rather than adding to the voices blaming (technological) rationality itself for the perennial misery of human history, we urge emancipatory actors both in and outside of science not to hypostatise technological development, separating it from the purposes it serves and its concrete embeddedness in social relations. The form of technological development should not be contemplated idealistically but rather understood as closely linked to societal conditions. 
In this, we follow Theodor W. Adorno, who argued that despite the fact that technological development in late capitalism is closely entangled with the reproduction of social domination, it would nonetheless be wrong to blame the existence of social domination on technological rationality itself. And although he states that this entanglement with social domination does not leave this rationality itself unaffected but profoundly reshapes it, his discussion of the "irrationality of ratio" in late capitalism nonetheless takes a more optimistic turn ([41], p. 91). Despite criticising that the immense achievements of modern society would only benefit a very small number of people and that socio-technical progress would threaten more and more to lead to the annihilation of humankind, he continues that it is not abstract science or rationality that is to blame. It is precisely the intertwining of science and technology with "very real" social conditions that leads to their orientation towards ends that are irrational because social conditions themselves are irrational ([41], p. 92).

And despite the apparent weakness of emancipatory forces today, Adorno reminds us that there remains a legitimate basis for critique: the insistence on the concretely and tangibly possible. He is particularly keen to highlight the potentials that the development of the productive forces offers for the creation of all necessary conditions for a dignified human existence and its reproduction on a global scale ([41], pp. 92-93). No one can deny, Adorno states, that a life free of hardship would be a concrete possibility-even in the poorest of countries. The main obstacles to its realisation would be of a political nature. Against this backdrop, not technology itself would be the issue, but, again, rather its entanglement with social conditions that would orient technological development towards profit and domination ([42], pp. 361-363).

It seems clear from this exposition, then, that despite the rejection of optimistic technological determinism and naïve belief in (socio-technical) progress, Adorno refuses to denounce science, technology and ratio in toto. Rather, he focuses on the entanglement of irrational social conditions and the mutilation of science and technology in their own image. Furthermore, he stresses the category of objective possibility as the fallback position for the formulation of critique in the face of rampant rationalised irrationality. And so do we: not the abstract and moral rejection of technological development altogether seems to us to be the task of critical thinking, but rather the confrontation of the present misery with the objective possibilities hampered by current social conditions.

However, ETS not only strives to develop a theory of technology in society but it also involves emancipatory practices of research itself. First and foremost, we believe that this includes a democratisation of the relationship between researcher and researched in the production of knowledge. In order for researchers to contribute to a dismantling of existing relations of domination, those who are subject to these relations must necessarily be included in the process proceedings. If we take the example of the digitalisation of work, however, most research focuses (critically) on managerial implementation strategies that use digital technologies for extensive surveillance or reduction of labour costs [43, 44]. Workers, on the other hand, appear as mere objects or victims of these processes. Yet, if we understand processes of emancipation as struggles against different forms of domination of those affected, workers must be at the centre of any analysis of ETS in the sphere of labour.

Various approaches have argued that in contexts of domination, such as capitalist enterprises, research inevitably becomes entangled in power relations. The role of the neutral observer is therefore an impossible ideal [45-47]. Thus, ETS cannot be limited to merely describing struggles for emancipation. Against this background, technology research in the social sciences, especially in industrial sociology, has developed various approaches in response to questions of research practice and engagement, among which "action research" has become a widely and commonly applied methodology. This approach aims at including workers in debates on, for instance, workplace design [48]. The aim is to place workers in the role of experts with their own analysis and design skills. These skills are then to be used in so-called "dialogue conferences", in which representatives of all status groups of a company agree on changes by consensus [49]. The concept of these dialogue conferences is based on Jürgen Habermas' ideal of a domination-free discourse. He understands this ideal as a largely unredeemed potential, which becomes the concrete reference point for possible emancipationalthough in most empirical cases, this assumption is counterfactual [50]. 
Yet, action research usually applies a highly simplified understanding by defining a discourse as free of domination if certain formal rules are followed: positions of power are not allowed to play a rolewhat counts is only the better argument. However, power resources in capitalist enterprises are structurally (and not only situationally) distributed highly asymmetrically, mainly in favour of the employers [51]. This asymmetry can only be obscured but not abolished by declaratory acts. The postulate of a liberation from domination in the workplace in the format of a dialogue conference will remain counterfactual as long as wage relations shape the relationship between the participants. If domination is officially declared absent, this can even exacerbate real power structures by giving them the cloak of democratic legitimacy. Therefore, the main objective of ETS is to offer novel and alternative ways to create participatory and transformative modes of knowledge production.

In empirical social research, this kind of sensitivity to domination is already important when entering the field. All social groups and organisations have institutional walls to keep out unwanted visitors. As in other contexts, the more powerful the actors behind these walls, the higher the walls. This fact needs to be reflected politico-ethically, on the one hand, and epistemologically, on the other hand. The more the field of research is characterised by domination, the more particularistic knowledge production tends to be ([45], p. 57). For example, managers have more opportunities to keep unwanted observers away than workers, which contributes to the fact that industrial sociological research has produced many surveys of workers and much less systematic research on managers. At the same time, managers have a greater chance of influencing the course of research in their company than workers. It is very difficult to carry out a case study without management approval. In turn, such approval will only be granted those who can plausibly demonstrate that they are useful to the company or the management. This has often led to research projects being made compliant with management despite a critical claim or to management being directly involved in implementation or reorganisation processes [46]. ETS must develop measures to prevent such managerial appropriation.

A similar sensitivity to power relations-but with a different objective-is required in research contexts beyond wage labour contexts, in which grassroots communities or individuals negatively affected by discrimination are at the centre of "the field". These groups often establish their own environments to find alternative ways of living or to resist potential forms of further domination. These environments are highly important spheres for gathering, discussing and exchanging in contexts of mutual respect, like-mindedness and care for each other. While ETS aims to make these concerns visible in order to raise awareness of the different forms of domination within societies, critical scholarship is at the same time confronted with their vulnerabilities. As Susan Leigh Star and Anselm Strauss put it: "some invisibility is strategic [...] and [...] may be positive as in autonomous control of the self, or negative, as in hiding shameful aspects" ([52], p. 23). Thus, keeping the institutional walls of such research fields as high as possible can also protect vulnerable groups from further discrimination and domination. Institutionalised places such as "safe spaces" are only one example of those kinds of walls that may sometimes deserve to remain untouched. Besides more obvious power asymmetries fuelled by managerial interests, being sensitive to these more subtle dynamics of power is an important approach that ETS likewise seeks to address.

This does not preclude the possibility of conducting design-oriented workshops as part of an empirical research project. However, such workshops must avoid stimulating a power equilibrium in order to produce consensus between conflicting parties. Hence, ETS puts particular emphasis on existing power relations and conflicts by acknowledging and critically investigating them. This also includes moving beyond the comfortable role of the neutral mediator that applied technology studies tend to take. Instead, any research linked to the normative goal of democratisation must aim at strengthening the position of those actors who are disadvantaged in a given relationship of domination. The role of the researcher then is to conduct systematic analyses in dialogue with disadvantaged groups of actors. Thus, instead of falling back into corporatist research, ETS advocates investigations together with those at the bottom of current societal hierarchies. Such a research strategy, as Luc Boltanski ([28], p. 150) puts it, "cannot involve anything other than a reinforcement of the role of critique. By this is to be understood two things: on the one hand, an increase in the strength of those who 
are its bearers and, on the other, the consolidation of its power- that is to say, its capacity to engage with reality in order to alter its contours". Thus, in ETS, the process of research itself is entangled with its objective of strengthening the role of emancipatory critique.

Against this background, ETS implies a reflexive engagement with its own normative standpoints regarding the relationship between researchers and those to be researched. Interactions between researchers and "their" research partners constitute a complex and power-laden relationship through which asymmetries of knowledge, expertise or material resources can become re-established. In order to identify and understand the manifold forms of possible emancipatory practices, emancipatory research should therefore involve a careful engagement with the actors under study. Current debates in STS highlight the complexity and yet importance of reflecting on different standpoints [53-55]. Therefore, it remains crucial to provide an alternative critique by asking cautiously and reflectively who the actors to be liberated are. The interest of ETS also lies in critically examining and flattening power asymmetries that may be established through the act of research itself, as it always entails practices of deciding and "silencing" certain voices in favour of a particular group of actors [45, 52]. Especially with regard to feminist and postcolonial scholars such as Harding [53] or Smith [56], ETS considers that research and the knowledge it produces are situated and always shaped by socio-political and economic conditions. Thus, ETS scholarship seeks to reflect on the status quo of current research practices and, more precisely, how their embedded sociopolitical values and experiences simultaneously shape how (and which) disadvantaged actors will be studied. In this vein, feminist scholarship argues that reflecting on "multiple standpoints" is of great importance since it makes power relations visible that are usually unseen or neglected when continuing to be investigated mainly from dominant viewpoints [57]. The latter approach runs the risk that marginalised standpoints are often neglected or examined, if at all, along stereotypical representations of those actors subject to domination. Considering these intersectional reflections thus implies a heterogeneous and context-specific understanding of emancipation. These considerations should ideally be integrated as reflections on what it means to pursue and practice ETS.
The contributions to this special section offer theoretical and methodological considerations which we hope will renew debates within (and beyond) scientific research on emancipation and technological development. While Georg Jochum's reflections enrich our theoretical understanding of emancipation, the paper by Johan Söderberg and Maxigas as well as the one by Alev Coban and Klara-Aylin Wenten add empirical analyses to the conceptual framework of ETS. The contributions by Simon Schaupp and Jamie Woodcock propose fresh analytical and methodological perspectives that help resolve the empirical challenges of integrating workers' resistant practices that often remain invisible in research on labour processes.

The contribution of Georg Jochum argues that the negative dialectics of emancipation must be problematised. He demonstrates how the project of emancipation, as formulated in the Age of Enlightenment, was often associated with the establishment of new forms of domination. Especially, the project of liberation from the constraints of nature through technical development led to the domination of nature itself. In view of the ecological crisis, the dark side of this project is becoming apparent today. Jochum therefore argues for the idea of a reflexive emancipation that also takes nature into account in order to enable sustainable technology development. ETS should in this sense support a positive dialectical movement that overcomes the contrast between submission to nature and technical mastery of nature.

Johan Söderberg and Maxigas stress the need for a new conceptual framework that develops and articulates (self-)critique more strongly in relation to the emancipatory potential of technology (development). By analysing emancipatory practices of hacker communities, the authors demonstrate that it is particularly their "functional autonomy" that allows hacker communities to sustain their independence and resistance to a potential reappropriation by capitalism. Their analysis puts forth the argument of attending more strongly to recuperation processes over longer time spans in order to better understand underlying mechanisms of domination, structural hierarchies and appropriation dynamics of capitalism. Söderberg's and Maxigas' interest in the emergence of emancipatory practices contributes to how ETS identifies and-in a second step-reduces power asymmetries 
by giving disadvantaged actors a voice in scientific analysis.

In their analysis on agile work, Alev Coban and Klara-Aylin Wenten point us to the often disregarded, invisible work practices of caring that are necessary to keep up with the imperative of new work organisation. Inspired by feminist STS, their analysis focuses on care in contexts of technology development and how such a perspective contributes to understanding power asymmetries in the workplace. In this vein, Coban and Wenten demonstrate how hierarchies emerge through the devaluation of essential practices of agile work. Their paper concludes with speculations on how a careful ETS discovers emancipatory potentials in contexts of wage labour and capitalist valuation systems when understanding care as practices embedded in ontological dependencies and not merely in asymmetrical relationships.

The contribution of Simon Schaupp develops a multi-level framework for the analysis of a bottom-up politics of technology in production. In researching how workers influence the use of algorithmic management systems, the article develops the concept of technopolitics to refer to three different arenas of negotiation: (1) the arena of regulation, where institutional framings of technologies in production are negotiated, typically between state actors, employers' associations and unions. (2) The arena of implementation, where strategies for technology deployment are negotiated-in the German production model, typically between management and works council. (3) The arena of appropriation, in which different organisational technocultures offer competing schemes for the actual use of technology at work. Thus, it can be demonstrated how workers influence the concrete outcome of digitalisation projects in the sense of "technopolitics from below".

Jamie Woodcock's contribution spells out the possibilities of a "digital workers inquiry". Drawing on various case studies and "workerist" theory, the article outlines the challenges and opportunities of combining research with organising for better working conditions. Thus, Woodcock asks how the process of inquiry and co-research and the methods they involve can be adapted and refined with digital technology. By starting the critique of technology from the workplace, he proposes an account of how technologies can be destroyed or reappropriated, beginning with a reading of workers' struggles.
In sum, the contributions in this special section aim to spark debate on emancipation in relation to technological development from a range of different disciplinary perspectives. This reflects our intention to bring the focus on emancipation back into the social sciences while developing fresh theoretical, methodological and empirical tools for us as researchers to study in cooperation with and in the interest of those subjected to domination.

Funding Open Access funding enabled and organized by Projekt DEAL.

Open Access This article is licensed under a Creative Commons Attribution 4.0 International License, which permits use, sharing, adaptation, distribution and reproduction in any medium or format, as long as you give appropriate credit to the original author(s) and the source, provide a link to the Creative Commons licence, and indicate if changes were made. The images or other third party material in this article are included in the article's Creative Commons licence, unless indicated otherwise in a credit line to the material. If material is not included in the article's Creative Commons licence and your intended use is not permitted by statutory regulation or exceeds the permitted use, you will need to obtain permission directly from the copyright holder. To view a copy of this licence, visit http://creativecommons.org/licenses/by/4.0/.

\section{References}

1. Haraway D (1980) In: Nicholson L (ed) Feminism/postmodernism. Routledge, London, pp 190-233

2. Hester H (2018) Xenofeminism. Medford, MA, Polity, Cambridge, UK

3. Wajcman J(2004) Technofeminism. Malden, MA, Polity, Cambridge, UK

4. Illich I (2001) Tools for conviviality. Marion Boyars, London

5. Srnicek N, Williams A (2015) Inventing the future: postcapitalism and a world without work. Verso, London

6. Scholz T (2016) Uberworked and underpaid: how workers are disrupting the digital economy. Malden, MA, Polity, Cambridge, UK

7. Woodcock J (2017) Working the phones: control and resistance in call centers, Reprint. Pluto Press, London

8. Cant C (2019) Riding for Deliveroo: resistance in the new economy. Polity, Cambridge, UK

9. Frey P, Schaupp S (2020) Futures of digital industry: technomanagerial or techno-political utopia? Behemoth 13:98-104

10. Pfeiffer S (2017) The vision of "Industrie 4.0" in the making - a case of future told, tamed, and traded. Nanoethics 11:107121. https://doi.org/10.1007/s11569-016-0280-3

11. Meyer U (2019) The emergence of an envisioned future. Sensemaking in the case of "Industrie 4.0" in Germany. Futures 109:130-141. https://doi.org/10.1016/j.futures.2019.03.001 
12. Bissell D, Birtchnell T, Elliott A, Hsu EL (2020) Autonomous automobilities: the social impacts of driverless vehicles. Curr Sociol 68:116-134. https://doi.org/10.1177/ 0011392118816743

13. Lipson H, Kurman M (2016) Driverless: intelligent cars and the road ahead. The MIT Press, Cambridge, MA

14. Lupton D (2014) Critical perspectives on digital health technologies. Sociol Compass 8:1344-1359. https://doi. org/10.1111/soc4.12226

15. Mahr D, Prüll L (1970). In: Buckermann P, Koppenburger A, Schaupp S (eds) Kybernetik, Kapitalismus, Revolutionen: Emanzipatorische Perspektiven im technologischen Wandel. Münster, Unrast, pp 161-190

16. Loader BD, Mercea D (2011) Networking democracy? Inf. Communication \& Society 14:757-769. https://doi. org/10.1080/1369118X.2011.592648

17. Sunstein CR (2018) \#Republic: divided democracy in the age of social media. Princeton University Press, Princeton, NJ

18. Carpenter CA (2010) The Obamachine: technopolitics 2.0. J Inform Tech Polit 7:216-225. https://doi. org/10.1080/19331681003765887

19. Schmid E, Knopf B, Pechan A (2016) Putting an energy system transformation into practice: the case of the German Energiewende. Energy Res Soc Sci 11:263-275. https://doi. org/10.1016/j.erss.2015.11.002

20. Markard J (2018) The next phase of the energy transition and its implications for research and policy. Nat Energy 3:628633. https://doi.org/10.1038/s41560-018-0171-7

21. Aronoff K, Battistoni A, Cohen DA, Riofrancos T (2019) A planet to win: why we need a Green New Deal. Verso Books, London

22. Klein N (2019) On fire: the burning case for a Green New Deal. Allen Lane

23. Marcuse H (1991) One-dimensional man: studies in the ideology of advanced industrial society. Beacon Press, Boston, MA

24. Krüger M, Frey P (2020) Neutralität, Objektivität, Normativität - Elemente einer kritischen Theorie der Technikfolgenabschätzung. In: Nierling L, Torgersen H (eds) Die neutrale Normativität der Technikfolgenabschätzung. Nomos, Berlin, pp 57-76

25. Haipeter T (2020) Digitalisation, unions and participation: the German case of “industry 4.0.” Ind Relat J 51:242-260. https:// doi.org/10.1111/irj.12291

26. Fuchs $C$ (2018) Industry 4.0: The digital German ideology. Triple C 1/16:280-289. https://doi.org/10.31269/triplec.v16i1.1010

27. Marx K (1976) Zur Kritik der Hegelschen Rechtsphilosophie. Einleitung. In: MEW Bd. 1. Dietz, Berlin, pp 378-391

28. Boltanski L (2011) On critique: a sociology of emancipation. Polity, Cambridge, UK

29. Acemoglu D, Restrepo P (2019) Robots and jobs: evidence from US labor markets. J Polit Econ 128:2188-2244. https:// doi.org/10.1086/705716

30. Brynjolfsson E, McAfee A (2014) The second machine age: work, progress, and prosperity in a time of brilliant technologies. W. W. Norton \& Company, New York

31. Frey CB, Osborne MA (2013) The future of employment: How susceptible are Jobs to computerisation? https://www. oxfordmartin.ox.ac.uk/downloads/academic/future-ofemployment.pdf

32. Zika G, Helmrich R, Maier T et al. (2018) Arbeitsmarkteffekte der Digitalisierung bis 2035: Regionale Branchenstruktur spielt eine wichtige Rolle. IAB-Kurzbericht

33. Stettes O (2019) Keine Angst vor Robotern - eine Aktualisierung: Beschäftigungseffekte der Digitalisierung - Befunde des Arbeitsmarktmonitoring des IW. Institut der Deutschen Wirtschaft, Köln

34. Noble DF (2011) Forces of production: a social history of industrial automation. Taylor \& Francis, New Brunswick, NJ

35. Wajcman J (2017) Automation: is it really different this time? Br J Sociol 68:119-127. https://doi. org/10.1111/1468-4446.12239

36. Delfanti A, Frey B (2020) Humanly extended automation or the future of work Seen through Amazon patents. Sci Technol Hum Values. https://doi.org/10.1177/ 0162243920943665

37. Frey P (2017) Automatisierung - (Alb-)Traum der emanzipatorischen Linken? $\mathrm{Zu}$ den gesellschaftspolitischen Implikationen avancierter Produktivkräfte. In: Buckermann P, Koppenburger A, Schaupp S (eds) Kybernetik, Kapitalismus, Revolutionen: Emanzipatorische Perspektiven im technologischen Wandel. Unrast, Münster, pp 109-123

38. Jochum G, Schaupp S (2019) Die Steuerungswende. Zur Möglichkeit einer nachhaltigen und demokratischen Wirtschaftsplanung im digitalen Zeitalter. In: Butollo F, Nuss S (eds) Marx und die Roboter: Vernetzte Produktion, Künstliche Intelligenz und lebendige Arbeit. Dietz, Berlin, pp 327-344

39. Wilkie A, Savransky M, Rosengarten M (2017) Speculative research: the lure of possible futures. Taylor \& Francis, London

40. Bloch E (1995) The principle of hope, vol 1. The MIT Press, Cambridge, MA

41. Adorno TW (2006) Zur Lehre von der Geschichte und von der Freiheit. Suhrkamp, Frankfurt a.M.

42. Adorno TW (1972) Spätkapitalismus oder Industriegesellschaft? Einleitungsvortrag zum 16. Deutschen Soziologentag. In: Adorno TW (ed) Soziologische Schriften I. Frankfurt a.M, Suhrkamp, pp 354-370

43. Dyer-Witheford N, Kjøsen AM, Steinhoff J (2019) Inhuman power: artificial intelligence and the future of capitalism. Pluto Press, London

44. Zuboff S (2019) The age of surveillance capitalism: the fight for the future at the new frontier of power. Profile Books, London

45. Burawoy M (2009) The extended case method. University of California, Berkeley, CA

46. Mayer-Ahuja N (2014) Forschung für wen? Arbeitssoziologie zwischen Beobachtung, Co-Management und Gesellschaftskritik. In: Jostmeier M, Georg A, Jacobsen H (eds) Sozialen Wandel gestalten: Zum gesellschaftlichen Innovationspotenzial von Arbeits- und Organisationsforschung. Springer, Wiesbaden, pp 353-362

47. Merchant C (1990) The death of nature: women, ecology, and the scientific revolution. HarperOne, New York 
48. Fricke W, Totterdill P (2004) Action research in workplace. Innovation and regional development. John Benjamins Publishing, Amsterdam

49. Gustavsen B (2015) Practical discourse and the notion of democratic dialogue. European J. of Workplace Innovation 1:1. https://doi.org/10.46364/ejwi.v1i1.163

50. Habermas J (1984) The theory of communicative action. Beacon Press, Boston, MA

51. Anderson E (2017) Private government: how employers rule our lives. Princeton University Press, Princeton

52. Star SL, Strauss A (1999) Layers of silence, arenas of voice: the ecology of visible and invisible work. Comput Supported Coop Work (CSCW) 8:9-30. https://doi.org/10.1023/A: 1008651105359

53. Harding S (1991) Whose science? Whose knowledge? Cornell University Press, Ithaca, NJ

54. Haraway D (1988) Situated knowledges: the science question in feminism and the privilege of partial perspective. Fem Stud 14:575-599. https://doi.org/10.2307/3178066
55. Campbell ND (2009) Reconstructing science and technology studies: views from feminist standpoint theory. Frontiers: A J. of Women Studies 30:1-29. https://doi.org/10.1353/ fro. 0.0033

56. Smith DE (1991) The conceptual practices of power: a feminist sociology of knowledge. Northeastern Univ Pr, Boston, MA

57. Harding S (2003) The feminist standpoint theory reader: intellectual and political controversies. Routledge, New York

Publisher's Note Springer Nature remains neutral with regard to jurisdictional claims in published maps and institutional affiliations. 